\title{
RETARDATION OF FOETAL DENTAL GROWTH IN RELATION TO PATHOLOGY
}

\author{
BY \\ MAURICE V. STACK \\ From the Medical Research Council Dental Research Unit, Bristol
}

(RECEIVED FOR PUBLICATION APRIL 1, 1963)

The most important phase of crown growth in the primary dentition is completed during the foetal period. Lower central incisors often show the cervical edge of the enamel and the beginning of root growth at term. Disturbances of foetal dental growth are rarely apparent; most of the hypoplasias seen on the teeth arise during the neonatal period (Massler and Schour, 1946). The commonest disturbance was associated by Rushton (1933) with the neonatal growth arrest.

Some defects shown by microscopy date from the prenatal period between the fourth and sixth months, as Sheldon, Bibby and Bales (1945) noted in association with vitamin $\mathbf{D}$ deficiency. Prenatal defects were noted by Kreshover, Clough and Bear (1958) in seven of 35 infants failing to survive birth or the neonatal period. Via and Churchill (1957) record a similar incidence of surface hypoplasias among 50 children with cerebral disorders whose births had been marked by poor respiration or prematurity. Hypoplasia was seen in seven of 16 children born to mothers with antepartum haemorrhage. Martin, Thompson and Castaldi (1960) believed that enamel defects in 13 of 15 premature children with cerebral palsy were of prenatal origin.

Previous quantitative studies have been concerned with duration or severe interference with growth as seen by microscopy or superficial examination. Delay in growth itself has been seen indirectly in a study by Falkner (1957) of a group of infants aged 6 to 12 months admitted to hospital. Inspection of the data suggests a three-week retardation in the timing of deciduous tooth eruption, compared with a group of infants not admitted. The total effect of factors acting prenatally or postnatally has thus not been evaluated so far.

Rates of growth of teeth provide the required evidence. These may be followed by measuring the rate of increase in tissue thickness, external dimensions, weights, or volumes. The overall growth status of the tooth is probably best expressed in terms of the weights of dry mineralized tissue. As such it has been found effective for the forensic assessment of foetal age (Stack, 1960).

Establishment of the relation between dentition weight and foetal age depended upon a survey of foetuses considered to be of normal growth and failing to survive only because of injury or asphyxia. Dental growth in foetuses not in these categories will be discussed in relation to pathology. The present study thus provides a more direct means of demonstrating the relation between delay in dental growth and pathological factors acting upon foetal growth. It is based upon dissections of developing deciduous dentitions following autopsy in 100 cases where duration of gestation was recorded together with pathological factors and other data.

\section{Method}

The range of apparently normal dental growth was first examined by tabulating tooth weight data on 40 dentitions from foetuses failing to survive birth because of asphyxia or injury and delivered after 38-42 weeks' gestation. The group mean was consistent with a regression line based upon dentitions representative of the 24th to the 38th weeks of gestation. Normal growth was therefore presumed in this smaller group characterized by pathology reports of immaturity and atelectasis (Stack, 1960). Regression became linear (Fig. 1) by transformation of the data-square roots of weights of central and lateral incisors and of first molars (sums of tooth pair weights, upper and lower jaws) were compared with foetal ages. Average error in estimating age by this means was less than one week when testing each case against the regression line for the group.

Data on 60 dentitions not conforming to the above criteria were compared with the 'normal' group. They were classified into five groups according to the pathological features noted at autopsy. One comprised miscellaneous or multiple factors (10 cases), two groups represented central nervous system defects (10 cases), and two larger groups were separated in order to determine whether maternal factors of pre-eclamptic toxaemia 


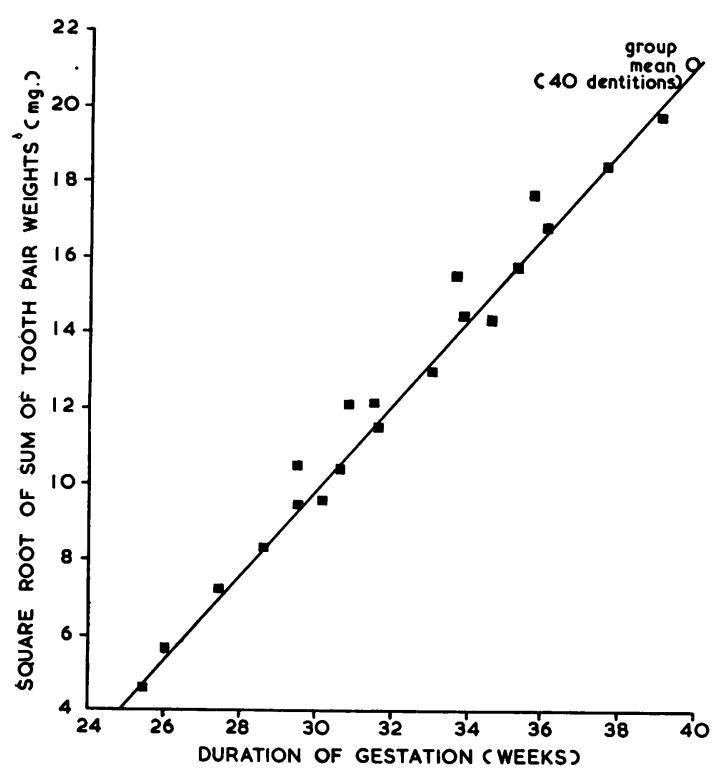

FIGURE.-Regression of square roots of sums of tooth pair weights on durations of gestation.

TABLE 1

DIFFERENCES BETWEEN ESTIMATED AND RECORDED FOETAL AGES IN RELATION TO SEX AND DURATION OF GESTATION ('normals')

\begin{tabular}{c|c|c|c}
\hline $\begin{array}{c}\text { Foetal Age Range } \\
\text { (days) }\end{array}$ & $\begin{array}{c}\text { Differences } \\
\text { (Mean } \pm \text { S.D.) }\end{array}$ & $\begin{array}{c}\text { Number } \\
\text { of Cases }\end{array}$ & Sex \\
\hline $267-286$ & $5 \pm 3$ & 15 & M \\
$287-298$ & $5 \pm 3$ & 10 & M \\
$266-294$ & $4 \pm 4$ & 15 & F \\
\hline
\end{tabular}

TABLE 2

DIFFERENCES BETWEEN ESTIMATED AND RECORDED FOETAL AGES

(Pathology: 'cardiac abnormalities')

\begin{tabular}{|c|c|c|c|}
\hline $\begin{array}{l}\text { Case No. } \\
\text { and } \\
\text { Sex }\end{array}$ & $\begin{array}{c}\text { Recorded } \\
\text { Age** } \\
\text { (days) }\end{array}$ & $\begin{array}{c}\text { Estimated } \\
\text { Age } \\
\text { (days) }\end{array}$ & Difference \\
\hline $\begin{array}{ll}106 & M \\
217 & M \\
051 & F \\
032 & M \\
264 & M \\
134 & M \\
206 & F \\
027 & M \\
048 & M \\
161 & M\end{array}$ & $\begin{array}{l}233 \\
238+4 \dagger \\
(245) \\
260 \\
265 \\
281 \\
283 \\
287 \\
291 \\
(287)+12 \dagger\end{array}$ & $\begin{array}{l}227 \\
247 \\
243 \\
257 \\
271 \\
274 \\
275 \\
282 \\
297 \\
296\end{array}$ & $\begin{array}{l}-6 \\
(+7) \\
(-2) \\
-3 \\
+6 \\
-7 \\
-8 \\
-5 \\
+6 \\
(+3)\end{array}$ \\
\hline & & & $\begin{array}{l}\text { Mean }-1 \\
\text { S.D. } \pm 6\end{array}$ \\
\hline
\end{tabular}

*Ages in parentheses were known to the nearest week.

+Total ages taken as 240 and 293 days respectively.
TABLE 3

DIFFERENCES BETWEEN ESTIMATED AND RECORDED FOETAL AGES

(Pathology: 'central nervous system abnormalities')

\begin{tabular}{|c|c|c|c|}
\hline $\begin{array}{l}\text { Case No. } \\
\text { and } \\
\text { Sex }\end{array}$ & $\begin{array}{c}\text { Recorded } \\
\text { Age* } \\
\text { (days) }\end{array}$ & $\begin{array}{c}\text { Estimated } \\
\text { Age } \\
\text { (days) }\end{array}$ & Difference \\
\hline $\begin{array}{ll}025 & \mathrm{~F} \\
081 & \mathrm{~F} \\
133 & \mathrm{~F} \\
024 & \mathrm{M} \\
123 & \mathrm{~F} \\
026 & \mathrm{~F} \\
023 & \mathrm{~F} \\
021 & \mathrm{M} \\
022 & \mathrm{~F} \\
138 & \mathrm{~F}\end{array}$ & $\begin{array}{c}(266) \\
269 \\
272 \\
280 \\
(280) \\
281 \\
281 \\
285 \\
291 \\
(297)\end{array}$ & $\begin{array}{l}272 \\
260 \\
280 \\
280 \\
260 \\
288 \\
274 \\
271 \\
276 \\
282\end{array}$ & $\begin{array}{c}(+6) \\
-9 \\
+8 \\
0 \\
(-20) \\
+7 \\
-7 \\
-14 \\
-15 \\
(-15)\end{array}$ \\
\hline & & & $\begin{array}{l}\text { Mean }-6 \\
\text { S.D. } \pm 10\end{array}$ \\
\hline
\end{tabular}

*Ages in parentheses were known to the nearest week.

TABLE 4

DIFFERENCES BETWEEN ESTIMATED AND RECORDED FOETAL AGES

(Pathology: 'pre-eclamptic toxaemia')

\begin{tabular}{|c|c|c|c|}
\hline $\begin{array}{l}\text { Case No. } \\
\text { and } \\
\text { Sex }\end{array}$ & $\begin{array}{c}\text { Recorded } \\
\text { Age* } \\
\text { (days) }\end{array}$ & $\begin{array}{c}\text { Estimated } \\
\text { Age } \\
\text { (days) }\end{array}$ & Difference \\
\hline \multirow[t]{2}{*}{$\begin{array}{ll}069 & \mathrm{M} \\
033 & \mathrm{~F} \\
107 & \mathrm{M} \\
060 & \mathrm{~F} \\
183 & \mathrm{~F} \\
113 & \mathrm{~F} \\
034 & \mathrm{~F} \\
114 & \mathrm{M} \\
036 & \mathrm{M} \\
120 & \mathrm{M} \\
155 & \mathrm{~F} \\
136 & \mathrm{~F} \\
173 & \mathrm{M} \\
038 & \mathrm{~F} \\
239 & \mathrm{M}\end{array}$} & $\begin{array}{c}226 \\
229 \\
245 \\
(245) \\
254 \\
264 \\
266 \\
270 \\
282 \\
283 \\
286 \\
290 \\
291 \\
291 \\
(294)\end{array}$ & $\begin{array}{l}223 \\
228 \\
229 \\
236 \\
244 \\
246 \\
260 \\
248 \\
278 \\
262 \\
279 \\
280 \\
291 \\
290 \\
293\end{array}$ & $\begin{array}{r}-3 \\
-1 \\
-16 \\
(-9) \\
-10 \\
-18 \\
-6 \\
-22 \\
-4 \\
-21 \\
-7 \\
-10 \\
0 \\
-1 \\
(-1)\end{array}$ \\
\hline & & & $\begin{array}{l}\text { Mean }-9 \text { days } \\
\text { S.D. } \pm 7 \frac{1}{2}\end{array}$ \\
\hline
\end{tabular}

*Ages in parentheses were known to the nearest week.

TABLE 5

DIFFERENCES BETWEEN ESTIMATED AND RECORDED FOETAL AGES

(Pathology: 'ante-partum haemorrhage')

\begin{tabular}{|c|c|c|c|}
\hline $\begin{array}{c}\text { Case No. } \\
\text { and } \\
\text { Sex }\end{array}$ & $\begin{array}{c}\text { Recorded } \\
\text { Age* } \\
\text { (days) }\end{array}$ & $\underset{\text { Age }}{\text { Estimated }}$ & Difference \\
\hline $\begin{array}{ll}066 & \mathrm{M} \\
101 & \mathrm{M} \\
062 & \mathrm{~F} \\
072 & \mathrm{~F} \\
105 & \mathrm{M} \\
199 & \mathrm{~F} \\
110 & \mathrm{M} \\
044 & \mathrm{M} \\
040 & \mathrm{M} \\
035 & \mathrm{M} \\
041 & \mathrm{M} \\
046 & \mathrm{~F} \\
118 & \mathrm{~F} \\
174 & \mathrm{M} \\
042 & \mathrm{~F}\end{array}$ & $\begin{array}{c}201 \\
214 \\
(224) \\
226 \\
233 \\
242 \\
249 \\
(252) \\
254 \\
265 \\
(266) \\
(266) \\
274 \\
274 \\
(280)\end{array}$ & $\begin{array}{l}200 \\
206 \\
206 \\
222 \\
218 \\
235 \\
238 \\
244 \\
236 \\
258 \\
251 \\
258 \\
257 \\
253 \\
261\end{array}$ & $\begin{array}{c}-1 \\
-8 \\
(-18) \\
-4 \\
-15 \\
-7 \\
-11 \\
(-8) \\
-18 \\
-7 \\
(-15) \\
(-8) \\
-17 \\
-21 \\
(-19)\end{array}$ \\
\hline
\end{tabular}

*Ages in parentheses were known to the nearest week. 
(15 cases) or ante-partum haemorrhage (15 cases) affected foetal dental growth.

Foetal ages were based upon estimated dates of delivery in 45 of the 60 cases, but they were known only to the nearest week in the remainder of the cases. A postnatal age of 12 days in one case $(161 \mathrm{M})$ was counted as adding six days' dental growth to a foetal age of 41 weeks. Similar adjustment was made in Case $217 \mathrm{M}$. All the other cases were stillbirths or neonatal deaths during the first day after birth. There was no association between viability at birth and age estimates from the teeth.

\section{Results}

The relation between age and the square root of the sum (W) of weights of all incisors and first molars approximated to:

$$
\text { Age (days) }=6\left(\mathrm{~W}^{\frac{1}{2}}+25\right) \text {. }
$$

Data on the 'normal' group were divided in Table 1 according to sex, because of the preponderance of male foetuses $(25: 15)$ and, in the case of males, also according to duration of gestation. The lower mean deviation in the female group was not significant-an opposite trend was seen when comparing males with females in the groups showing retarded dental growth.

Table 2 indicates no significant retardation in the group characterized by cardiac abnormalities. Table 3, however, suggests that abnormalities of the central nervous system led to age being underestimated by nearly a week, a significant difference $(p=0.02)$ as were those for the other group means. Tables 4 and 5 present data associated with evidence of placental inadequacy, underestimates of age tending to be more pronounced in cases of maternal ante-partum haemorrhage than in pre-eclampsia (not significant).

Table 6 shows more pronounced delay in dental growth, amounting to a mean of two weeks, among cases where there were miscellaneous or multiple abnormalities. Table 7 summarizes the distribution of differences between ages as estimated and recorded, both in the control group and in Groups 4, 5 and 6-all the differences were negative in the abnormal cases. Overall deficiency in body weight was equivalent to about three weeks' growth, but the standard deviation was also about three weeks.

\section{Discussion}

Differences between recorded and estimated ages are within the limits found for the 'normal' group in nearly half the 60 cases in the abnormal groups, and a similar proportion was noted in each of the four sub-groups showing overall retarded growth of the dentition. It is thus not possible to predict that retarded growth will be observed in cases where the pathology indicates this likelihood. Better
TABLE 6 DIFFERENCES BETWEEN ESTIMATED AND RECORDED

(Pathology: 'multiple/miscellaneous abnormalities')

\begin{tabular}{c|c|c|c}
\hline $\begin{array}{c}\text { Case No. } \\
\text { and } \\
\text { Sex }\end{array}$ & $\begin{array}{c}\text { Recorded } \\
\text { Age* } \\
\text { (days) }\end{array}$ & $\begin{array}{c}\text { Estimated } \\
\text { Age } \\
\text { (days) }\end{array}$ & Difference \\
\hline 109 M & 252 & 237 & -15 \\
108 F & 255 & 237 & -18 \\
$175 \mathrm{M}$ & 258 & 256 & -2 \\
$184 \mathrm{~F}$ & 262 & 241 & -21 \\
$058 \mathrm{~F}$ & $(266)$ & 244 & $(-22)$ \\
$124 \mathrm{M}$ & $(267)$ & 259 & $(-8)$ \\
$078 \mathrm{M}$ & $(268)$ & 261 & -3 \\
$127 \mathrm{M}$ & 271 & 268 & -22 \\
$191 \mathrm{~F}$ & 280 & 258 & 261 \\
$220 \mathrm{~F}$ & 283 & & Mean -14 days \\
\hline & & & S.D. \pm 8
\end{tabular}

*Ages in parentheses were known to the nearest week.

TABLE 7

DIFFERENC:ES BETWEEN ESTIMATED AND RECORDED FOETAL AGES

(Pathology: 'as in Tables 4, 5 and 6')

Numbers of normals and abnormals

\begin{tabular}{|c|c|c|c|c|c|}
\hline Difference (days) & $0-3$ & 4-6 & 7-9 & $10-12$ & $13-$ \\
\hline $\begin{array}{l}\text { Normals } \\
\text { Abnormals ... }\end{array}$ & $\begin{array}{r}19 \\
8\end{array}$ & $\begin{array}{r}12 \\
4\end{array}$ & $\begin{array}{l}5 \\
8\end{array}$ & $\begin{array}{l}3 \\
3\end{array}$ & $\begin{array}{r}1 \\
17\end{array}$ \\
\hline
\end{tabular}

correlation would probably have been observed had the duration and severity of maternal preeclampsia and/or haemorrhage been known. The miscellaneous sub-group probably included cases where the pathology was without effect on dental growth.*

The apparently non-specific growth response of the dentition to pathological events affecting the foetus is in line with what has been observed in studying actual disorders of tooth growth evidenced by enamel hypoplasia. These are sometimes evident in normal children born to mothers whose pregnancies were apparently uneventful. Nevertheless, a definite correlation has been noted between the timing of abnormal events and of hypoplasia by Via and Churchill (195S). Only eight of 219 children with some form of cerebral disorder showed prenatal hypoplasia not associated with premature birth. They suggested that generalized physiological disorders affected the teeth in cases of central nervous system diseases.

The present data indicate that central nervous system abnormalities are less disturbing than the maternal factors listed in Tables 4 and 5. Other maternal factors affecting gestation, and for which the extent of dental disturbance is unknown,

* Case 175: Cerebral infarct, pulmonary and adrenal haemorrhage; Case 127: Injury, hydroceles; Case 78: Injury, hydronephrosis; Case 124: Exomphalos operation, peritonitis, injury. 
include infections and intoxications, diabetes and renal disease, and radiation accidents. Kreshover et al. (1958) refer to their studies of interference with development of foetal dentitions in animals by inducing maternal pyrexia and alloxan diabetes, whereas there was no response to infection with vaccinia virus.

\section{Summary}

Association between abnormal foetal and maternal conditions and growth of the dentition has been demonstrated quantitatively by gravimetric observations on the partially formed crowns of incisors and first molars. Comparison was made with a 'normal' group comprising 40 dentitions representative of foetuses delivered after 38-42 weeks' gestation and failing to survive because of asphyxia or injury. No retardation in dental growth was demonstrable in relation to cardiac defects (10 cases), but estimates of foetal age from the selected teeth were one week low in foetuses with central nervous system defects (10 cases). Delay was significantly greater among 15 cases with maternal histories of pre-eclampsia, 15 cases with maternal histories of ante-partum haemorrhage, and among 10 cases where the pathological factors were miscellaneous or multiple, foetal dental growth being retarded by an average of two weeks in these cases.

Grateful thanks are due to Dr. Norman J. Brown, Consultant Pathologist to the Southmead Hospital Group, Bristol, for generously providing access to material and departmental records, and for his advice on classification, complemented by that of Mr. T. M. Abbas while Lecturer in the Department of Obstetrics and Gynaecology, University of Bristol.

\section{REFERENCES}

Falkner, F. (1957). Deciduous tooth eruption. Arch. Dis. Childh., 32,386

Kreshover, S. J., Clough, O. W. and Bear, D. M. (1958). A study of prenatal influences on tooth development in humans. J. Amer. dent. Ass., 56, 230.

Martin, J. K., Thompson, M. W. and Castaldi, C. R. (1960). A study of the clinical history, tooth enamel and dermal patterns in 175 cases of cerebral palsy. Guy's Hosp. Rep., 109, 139.

Massler, M. and Schour I (1946). The appositional life span of the enamel- and dentin-forming cells. I. Human deciduous teeth enamel- and dentin-forming cells. I. Human decid
and first permanent molars. J. dent. Res., $25,145$.

Rushton, M. A. (1933). On the fine contour lines of the enamel of milk teeth. Dent. Rec., 53, 170.

Sheldon, M., Bibby, B. G. and Bales, M. S. (1945). The relationship between microscopic enamel defects and infantile debilities. J. dent. Res., 24, 109.

Stack, M. V. (1960). Forensic estimation of age in infancy by gravimetric observations on the developing dentition. J. forens.
Sci. Soc., 1, 49 .
W. F., Jr. and Churchill, J. A. (1957). Relationships of cerebral

Via, W. F., Jr. and Churchill, J. A. (1957). Relationships of cerebral
disorder to faults in dental enamel. A.M.A. Amer. J. Dis. disorder to faults in dental enamel. A.M.A. Amer. J. Dis.
Child., 94, 137. events of gestation and birth. J. Amer. dent. Ass., 59, 702. 